FACTA UNIVERSITATIS

Series: Economics and Organization Vol. 15, No 4, 2018, pp. 319 - 329

https://doi.org/10.22190/FUEO1804319J

Original Scientific Paper

\title{
THE EFFECTS OF VOLATILITY SPILLOVER ON THE LARGEST GLOBAL FINANCIAL MARKET SEGMENTS
}

\author{
UDC 336.76
}

\section{Irena Janković}

University of Belgrade, Faculty of Economics, Belgrade, Serbia

\begin{abstract}
The aim of the paper is to present and analyse indicators of financial connectedness and volatility spillover on important segments of the global financial market - the stock market, bond market, CDS market, and foreign exchange market. Total, net, and directional measures of volatility spillover are presented and analysed, indicating the level of connectedness of countries' particular market segments and the level of volatility spillover in periods of crisis and stability.
\end{abstract}

Key words: financial connectedness, generalised VAR, volatility spillovers, global financial market segments

JEL Classification: G01, G15, C32, E44

\section{INTRODUCTION}

Financial connectedness is an important characteristic of global financial markets. Its level and behaviour are very significant for financial risk measurement and management. Volatility spillover effects have a direct effect on the market and credit risk, with possible pronounced systemic consequences, particularly in crisis periods. Throughout history, the crises have tended to occur at regular intervals and have often had similar consequences (Reinhart \& Rogoff, 2008). During crises, volatility usually increases and spills over into other markets and asset classes. Thus, it is important to measure and record volatility spillovers for at least two reasons: to get early warning signals of upcoming crises and/or to follow the duration of the ongoing one.

Diebold and Yilmaz (2012) propose volatility spillover measures based on forecast error variance decompositions from vector autoregressions (VARs). VAR variance decompositions present how much of the $H$-step-ahead forecast error variance of a variable $i$ is due to

Received September 10, 2018 / Accepted October 31, 2018

Corresponding author: Irena Janković

University of Belgrade, Faculty of Economics, 11000 Belgrade, Kamenička 6, Serbia

E-mail: irenaj@ekof.bg.ac.rs 
innovations in another variable $j$ (Sims, 1980). Spillover measures based on variance decompositions are interesting because they could provide an answer to the question of how much of a variable's $i$ future uncertainty is due to shocks occurring at variable $j$. In addition, they allow for spillover at different time horizons. The proposed indicators can be used to measure and track volatility spillover across asset classes, portfolios, and markets, both within and between countries. They propose total and directional spillover measures. The total volatility spillover measure shows spillover from (to) each market $i$, to (from) all other markets, added across $i$. Directional spillovers offer a more detailed picture of volatility spillover from (to) a particular market. Besides investigating spillovers across identical asset classes in various countries, or the same asset class within one country across different industry sectors, of even more profound interest is the spillover effect among different asset classes. Volatility spillover between different asset classes is especially interesting when investigating different crisis periods. In the last global crisis the spillover happened from credit markets to equity markets, with further effects on bond and commodity markets. The transmission of volatility shocks has significant effects on portfolio choices and asset allocation.

\section{LITERATURE REVIEW}

The main econometric methods for estimation of volatility spillovers are the GARCHbased and VAR-based models.

Diebold and Yilmaz (2009) developed a VAR-based volatility spillover measure which was later modified and improved. Based on the generalised vector autoregressive framework in which forecast-error variance decompositions are invariant to the variable ordering, Diebold and Yilmaz (2012) propose measures of total and directional volatility spillovers. They estimate daily volatility spillovers across the US stock, bond, foreign exchange, and commodity markets over a ten year period from January 1999 to January 2010, and show that although significant volatility fluctuations were present in all four markets, cross-market volatility spillovers were limited until the global financial crisis. As the crisis intensified, so did the volatility spillovers, with particularly important spillovers from the stock market to other markets after the collapse of Lehman Brothers in September 2008.

Many studies have used Diebold and Yilmaz's procedure to estimate volatility spillovers.

Duncan and Kabundi (2013) use and extend the spillover methodology. They analyse domestic and foreign sources of volatility spillover for South African bonds, commodities, currencies, and equities. Based on the data for the period 1996-2010, they investigate bidirectional spillovers between domestic assets and volatility coming from shocks in the global financial market. They find that spillovers increased during both domestic and foreign crises, and that domestic spillovers significantly exceeded foreign spillovers. Their findings suggest a high level of systemic risk that was mostly related to internal factors. The main transmitters of spillovers were shocks in commodity and equity markets.

Alter and Beyer (2012) extend Diebold and Yilmaz's methodology and develop measures of the strength of spillover effects. They quantify spillovers between sovereign credit markets and banks in the euro area. Spillovers are estimated based on daily CDS spread changes. They take into account interdependencies between sovereign and bank CDS spreads and assess the systemic effect of an unexpected shock to the creditworthiness of a particular sovereign or country-specific bank index on other sovereign or bank CDSs in 
the period October 2009-July 2012. Their Contagion Index measures the average potential spillover among sovereigns, among banks, from sovereigns to banks, and from banks to sovereigns. The results show growing interdependency between banks and sovereigns, which represents a potential source of systemic risk and contagion.

Antonakakis and Vergos (2013) explore sovereign yield spread spillovers between the eurozone core and periphery countries in the periods of global and sovereign debt crisis in Europe. They calculate the spillover indices of Diebold and Yilmaz (2012) and conclude that bond yield spread shocks coming from the periphery eurozone countries to the core eurozone countries have an effect on the core countries that is three times stronger than vice versa. They stress the increased vulnerability of the eurozone from shocks originating predominantly in the periphery countries.

Louzis' (2015) study examines volatility spillovers between the eurozone money, stock, foreign exchange, and bond markets. Their empirical results, based on the data for the period 2000-2012, suggest a high level of total volatility spillover. The stock markets across the eurozone are identified as the main transmitters of volatility spillover, while for the most part the core countries transmit volatility spillovers to the periphery. The money, FX, and bond markets are receivers of spillovers, with the exception of Greek bonds, which transmitted spillovers during the Greek sovereign debt crisis in 2011-2012.

\section{Methodology OVERVIEW}

Diebold and Yilmaz initially based their total spillover measure on a simple VAR framework (with possible order-dependent results due to the Cholesky factor orthogonalisation) and progressed to directional measures (Diebold \& Yilmaz, 2009). The methodology to calculate the directional volatility spillover measures is based on the generalized VAR, in which forecast-error variance decompositions are invariant to the variable ordering (Diebold \& Yilmaz, 2012). The proposed methodology is based on variance decomposition on an $\mathrm{N}$-variable $\operatorname{VAR}(p)$.

The starting point is a covariance stationary $N$-variable $\operatorname{VAR}(p), x_{t}=\sum_{\mathrm{i}=1}^{p} \Phi_{\mathrm{i}} x_{t-i}+\varepsilon_{t}$, where $\varepsilon \sim(0, \Sigma)$ is a vector of independently and identically distributed disturbances. The moving average presentation is $x_{t}=\sum_{i=0}^{\infty} \mathrm{A}_{\mathrm{i}} \varepsilon_{t-i}$, where the $N \times N$ matrices of coefficients $A_{i}$ complies with recursion $A_{i}=\Phi_{1} A_{i-1}+\Phi_{2} A_{i-2}+\ldots+\Phi_{\mathrm{p}} A_{i-p}$, where $A_{0}$ is a $N \times N$ identity matrix and $A_{i}=0$ for $i<0$. The moving average coefficients are very important for understanding the dynamics of the system. The variance decompositions allow the division of each variable's forecast error variance into parts that are attributable to different system shocks. In addition, they allow assessing the part of the $H$-step ahead of error variance in forecasting $x_{i}$ that is due to schocks in $x_{j}$, where $\forall j \neq i$, for each $i$.

In order to calculate variance decompositions, orthogonal innovations are required, whereas VAR innovations are generally contemporaneously correlated. Identification schemes based on the Cholesky factorisation achieve orthogonality, but the variance decompositions then depend on the ordering of the variables. Hence, the generalized VAR framework of Koop, Pesaran, and Potter (1996) and Pesaran and Shin (1980), KPPS, is followed here, which produces variance decompositions that are invariant to ordering. Instead of the attempt to orthogonalise shocks, the generalised approach allows for correlated shocks but accounts appropriately for the correlation using the historically observed distribution of the errors. Since shocks to each variable are not orthogonalised, the sum of the contributions to the variance of the forecast error does not have to be equal to one. 


\subsection{Variance shares}

Own variance shares are the fractions of the $H$-step-ahead error variances in forecasting $x_{i}$ that are due to shocks to $x_{i}$, for $i=1,2, \ldots, N$. On the other hand, cross variance shares or spillovers are fractions of the $H$-step-ahead error variances in forecasting $x_{i}$ that are due to shocks to $x_{j}$, for $i, j=1,2, \ldots, N$, such that $i \neq j$.

KPPS $H$-step-ahead forecast error variance decompositions are denoted by $\theta_{i j}^{g}(H)$, and for $H=1,2, \ldots$, as follows

$$
\theta_{i j}^{g}(H)=\frac{\sigma_{j j}^{-1} \sum_{h=0}^{H-1}\left(e_{i}^{\prime} A_{h} \Sigma e_{j}\right)^{2}}{\sum_{h=0}^{H-1}\left(e_{i}^{\prime} A_{h} \Sigma A_{h}^{\prime} e_{j}\right)}
$$

where $\Sigma$ is the variance matrix for error vector $\varepsilon, \sigma_{j j}$ is the standard deviation of the error term for the $j$ th equation, and $e_{i}$ is the selection vector having 1 as the $i$ th element and 0 otherwise. Since the sum of elements in each row of the variance decomposition table is not equal to 1 , as previously stated, in order to be able to use the decomposition matrix in the calculation of the spillover measure, each element of the variance decomposition matrix is normalised by the row sum:

$$
\tilde{\theta}_{i j}^{g}(H)=\frac{\theta_{i j}^{g}(H)}{\sum_{j=1}^{N} \theta_{i j}^{g}(H)}
$$

where $\sum_{j=1}^{\mathrm{N}} \tilde{\theta}_{\mathrm{ij}}^{\mathrm{g}}(\mathrm{H})=1$ and $\sum_{\mathrm{i}, \mathrm{j}=1}^{\mathrm{N}} \tilde{\theta}_{\mathrm{ij}}^{\mathrm{g}}(\mathrm{H})=\mathrm{N}$.

\subsection{Total volatility spillover measure}

Total volatility spillover index is based on volatility contributions from the KPPS variance decomposition:

$$
S^{g}(H)=\frac{\sum_{i, j=1, i \neq j}^{N} \tilde{\theta}_{i j}^{g}(H)}{\sum_{i, j=1}^{N} \tilde{\theta}_{i j}^{g}(H)} \times 100=\frac{\sum_{i, j=1, i \neq j}^{N} \tilde{\theta}_{i j}^{g}(H)}{N} \times 100
$$

This index measures the contribution of volatility shock spillovers across asset classes to the total forecast error variance (Diebold \& Yilmaz, 2012, p.59).

\subsection{Directional volatility spillover measures}

Generalized VAR enables comprehending in more detail the direction of the volatility spillovers across different asset classes. Directional indices are calculated based on normalised elements of the generalised variance decomposition matrix.

Directional volatility spillovers received by market $i$ from all other markets $j$ are presented as:

$$
S_{i .}^{g}(H)=\frac{\sum_{j=1, j \neq i}^{N} \tilde{\theta}_{i j}^{g}(H)}{\sum_{i, j=1}^{N} \tilde{\theta}_{i j}^{g}(H)} \times 100=\frac{\sum_{j=1, j \neq i}^{N} \tilde{\theta}_{i j}^{g}(H)}{N} \times 100
$$


Directional volatility spillovers transmitted by market $i$ to all other markets $j$ is denoted in a similar way:

$$
S_{. i}^{g}(H)=\frac{\sum_{j=1, j \neq i}^{N} \tilde{\theta}_{i j}^{g}(H)}{\sum_{i, j=1}^{N} \tilde{\theta}_{i j}^{g}(H)} \times 100=\frac{\sum_{j=1, j \neq i}^{N} \tilde{\theta}_{i j}^{g}(H)}{N} \times 100
$$

Directional measures represent a decomposition of total spillover to spillovers coming from (or to) a specific source.

\subsection{Net volatility spillover measures}

Net volatility spillover from market $i$ to all other markets $j$ can be calculated as:

$$
S_{i}^{g}(H)=S_{\cdot i}^{g}(H)-S_{i .}^{g}(H)
$$

It is the difference between volatility shocks transferred to and received from all other markets. It provides information about how much, in net terms, each market contributes to the volatility of other markets.

\subsection{Net pairwise volatility spillover measures}

Finally, net pairwise volatility spillovers are defined as:

$$
S_{i j}^{g}(H)=\left(\frac{\tilde{\theta}_{j i}^{g}(H)}{\sum_{i, k=1}^{N} \tilde{\theta}_{i k}^{g}(H)}-\frac{\tilde{\theta}_{i j}^{g}(H)}{\sum_{j, k=1}^{N} \tilde{\theta}_{j k}^{g}(H)}\right) \times 100=\left(\frac{\tilde{\theta}_{j i}^{g}(H)-\tilde{\theta}_{i j}^{g}(H)}{N}\right) \times 100
$$

The net pairwise volatility spillover between markets $i$ and $j$ is the difference between the gross volatility shocks transmitted from market $i$ to market $j$ and those transmitted from market $j$ to market $i$.

\section{SPILlOVER IndiCES FOR MAIN GLOBAL FinANCIAL MARKET SEGMENTS}

In this part of the paper, volatility spillover indices are presented and analysed for important global market segments: the equity market, bond market, CDS market, and FX market. $^{2}$

Figure 1 represents the volatility spillover index methodology applied to 45 countries' stock market index returns for the period $8^{\text {th }}$ June 2004 to $17^{\text {th }}$ August 2018.

\footnotetext{
${ }^{2}$ The calculation of all spillover indices presented is based on generalised variance decompositions (with a 10-day forecast horizon) from a VAR(3) model.
} 


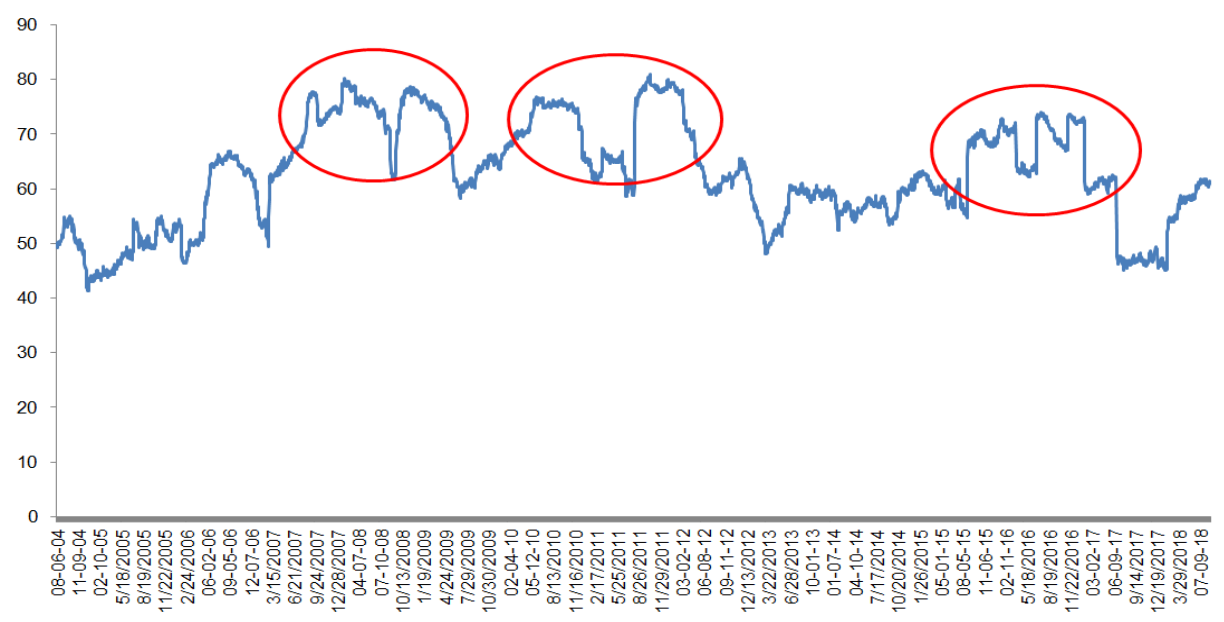

Fig. 1 Global stock markets - volatility spillover index

Source: Author's presentation based on data from Diebold-Yilmaz database, http://financialconnectedness.org/research.html

Global equity volatility spillover index movement for the analysed period indicates significant changes in volatility spillover dynamics, with a profound increase in the three crisis sub-periods: the global financial crisis, the debt crisis in the eurozone, and Brexit. The increase in volatility spillovers in the crisis periods to over 80 index points confirms the shock effects that have already happened in the global stock market and provides a basis for using the spillover index as a warning signal of the upcoming crisis episodes.

Figure 2 represents volatility spillover index methodology applied to 10-year government bond return volatilities in 12 major economies over the period $8^{\text {th }}$ August 2000 to $16^{\text {th }}$ May 2018.

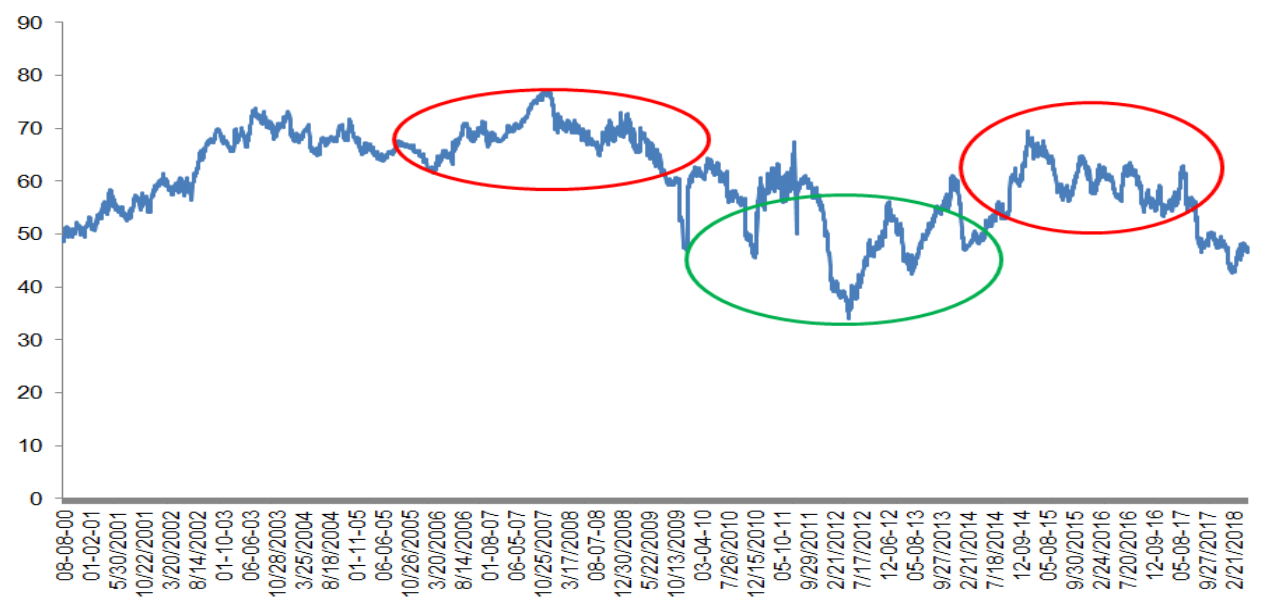

Fig. 2 Bond markets - volatility spillover index

Source: Author's presentation based on data from Diebold-Yilmaz database, http://financialconnectedness.org/research.html 
The volatility spillover index for bonds markets shows an expected increase in the 2007-2008 crisis period, but less than for the stock market. Interestingly, in the sovereign debt crisis in the eurozone the volatility spillover index in bond markets increased initially, and then soon after 2011 decreased to a historically low level. This may be explained by the fact that the monetary policy in the eurozone changed significantly after the crisis started and its expansionary orientation reduced interest rates to an extremely low level, even into the negative zone for the strongest economies. Thus, the initial spillover of shocks was stopped.

Figure 3 represents volatility spillover index methodology applied to return volatilities of the USD exchange rate against 28 currencies over the period $13^{\text {th }}$ October 2000 to $17^{\text {th }}$ August 2018.

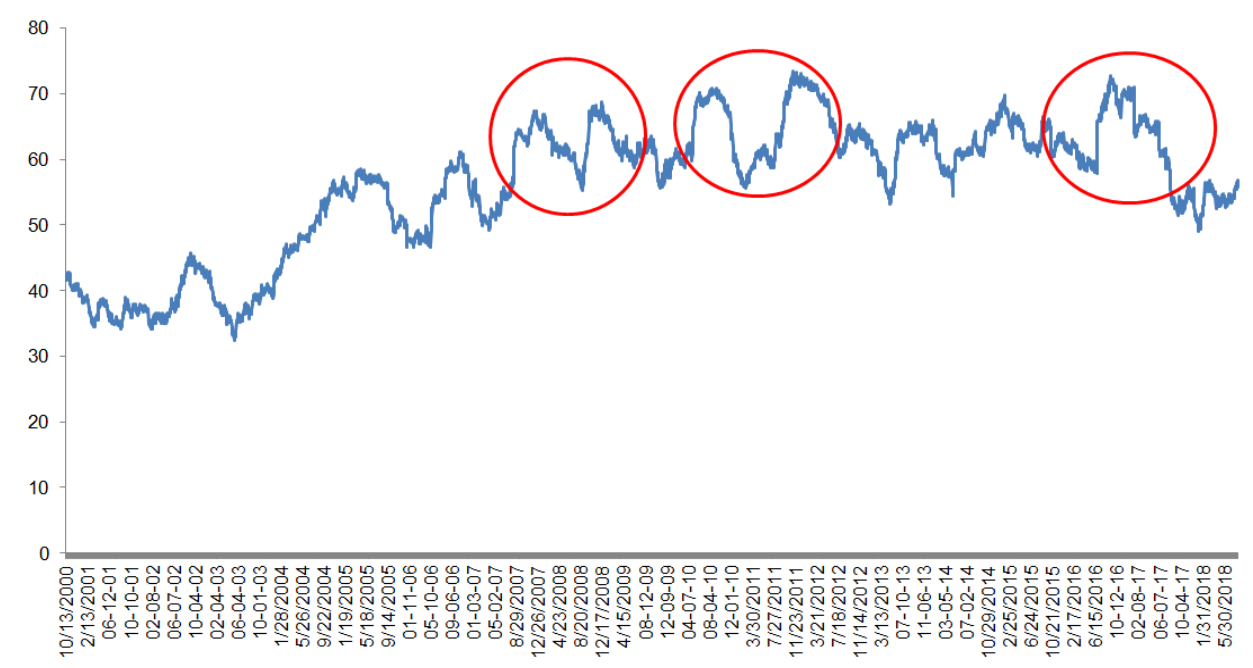

Fig. 3 FX markets - volatility spillover index

Source: Author's presentation based on data from Diebold-Yilmaz

database, http://financialconnectedness.org/research.html

During the previously considered three crisis periods the total volatility spillover index for the FX market showed a similar pattern to the equity volatility behaviour, indicating significant changes in the volatility spillover dynamics, which again reached maximum levels in the crisis periods.

Figure 4 represents volatility spillover index methodology applied to the credit default swap returns for 5-year government bonds in 26 countries over the period from $1^{\text {st }}$ September 2009 to $22^{\text {th }}$ December 2017. 


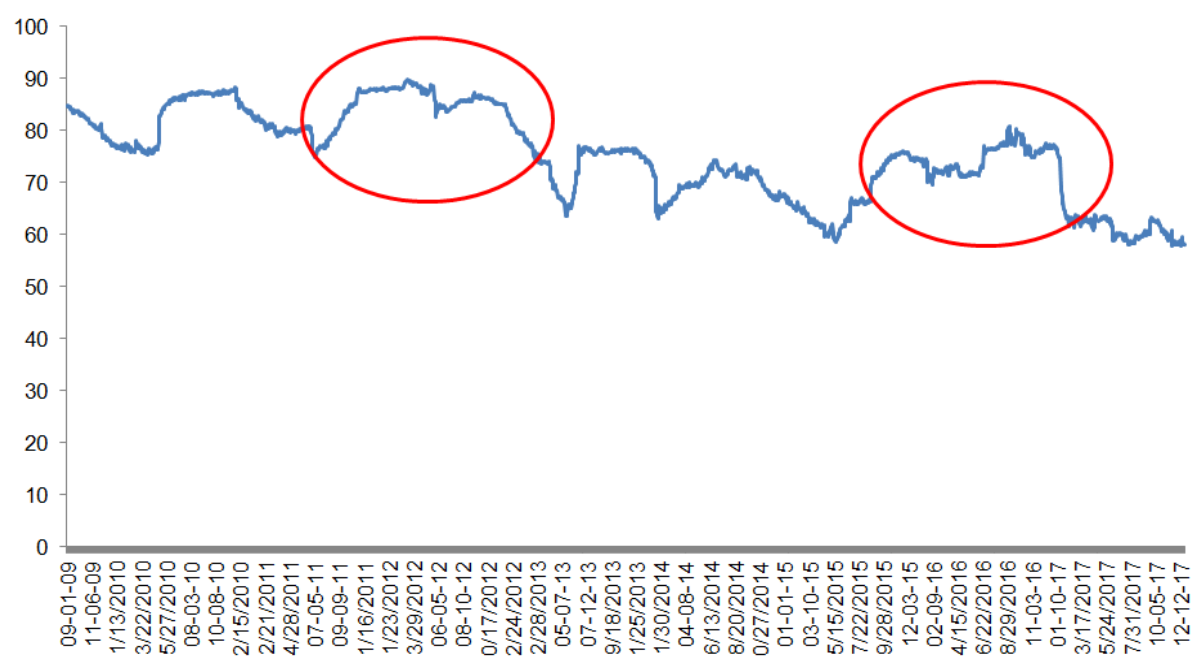

Fig. 4 CDS markets - volatility spillover index

Source: Author's presentation based on data from Diebold-Yilmaz database, http://financialconnectedness.org/research.html

The CDS spreads volatility index has the highest level of all four investigated asset classes, with the strongest increases during the eurozone crisis and Brexit. The increases in the index show a rising spillover of volatility shocks and default risk, with a possible contagion effect among markets.

The next table summarises volatility spillover indicators by providing minimum, maximum, and average values of the index for the presented periods and asset classes. The maximum spillover index is recorded for the CDS and equity markets, followed by the bond and FX markets.

Table 1 Comparative analysis of volatility spillover for main global market segments

\begin{tabular}{lccc}
\hline & Min & Max & Average \\
\hline Stock market & 41.26 & 80.98 & 62.76 \\
Bond market & 33.96 & 77.05 & 60.21 \\
FX market & 32.33 & 73.46 & 56.20 \\
CDS market & 57.75 & 89.88 & $\mathbf{7 5 . 2 2}$ \\
\hline
\end{tabular}

Source: Author's calculation based on data from Diebold-Yilmaz database, http://financialconnectedness.org/research.html

When referring to the dataset indicating volatility shock spillover from all other markets to a particular market, the countries whose markets receive most volatility shocks from others in times of distress include France, the Netherlands, Germany, Belgium, Italy, the UK, and Spain, followed by other developed and more open countries in economic and financial terms. At the bottom of the list are mostly developing and less integrated countries (Fig. 5). 


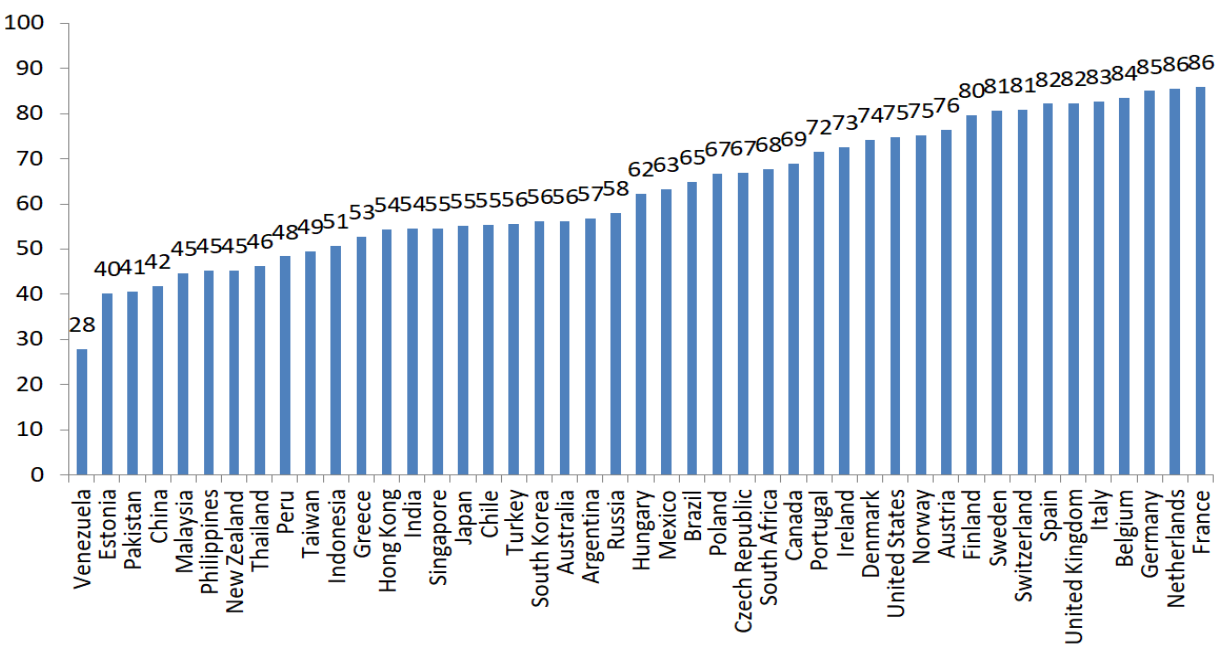

Fig. 5 Average directional volatility spillover from all other stock markets to a particular market

Source: Author's calculation and presentation based on data from Diebold-Yilmaz database, http://financialconnectedness.org/research.html

A similar result is found for the second directional spillover measure, indicating the spillover from a particular market to all other markets. More developed and integrated markets face greater spillover effects, especially in times of crisis when contagion effects are pronounced (Fig. 6).

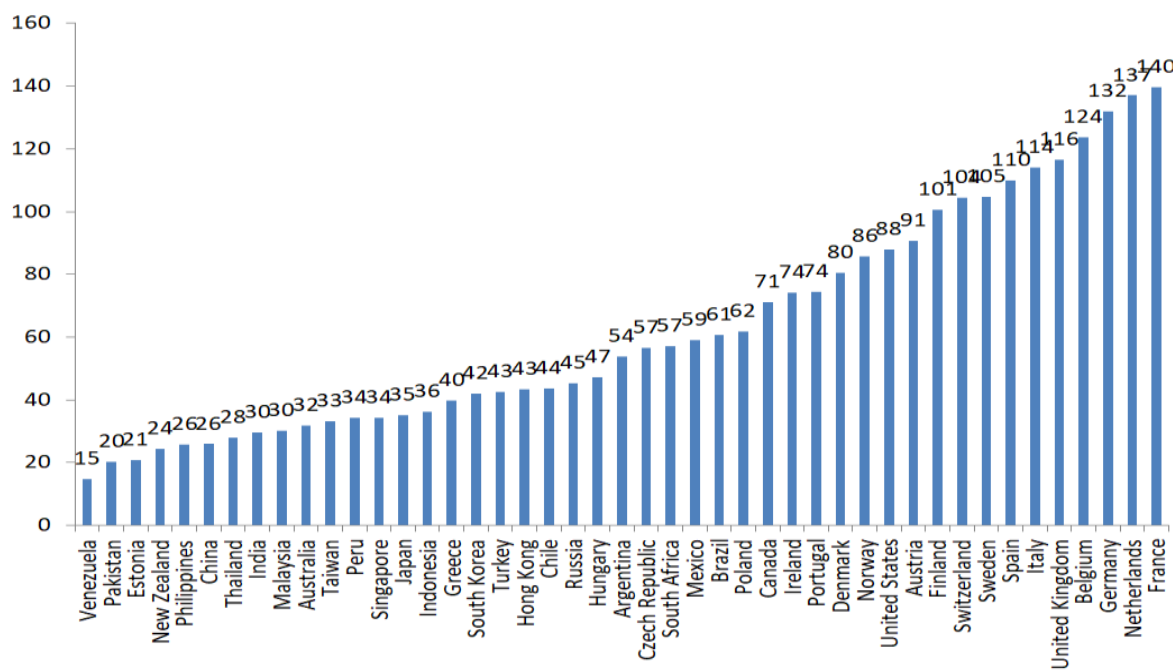

Fig. 6 Average directional volatility spillover to other stock markets from a particular market Source: Author's calculation and presentation based on data from Diebold-Yilmaz database, http://financialconnectedness.org/research.html 
The following chart presents the net directional volatility spillover index across different markets. Positive values of the index indicate countries where volatility spillover is initiated. A negative value of the index indicates when a country is the net receiver of shocks.

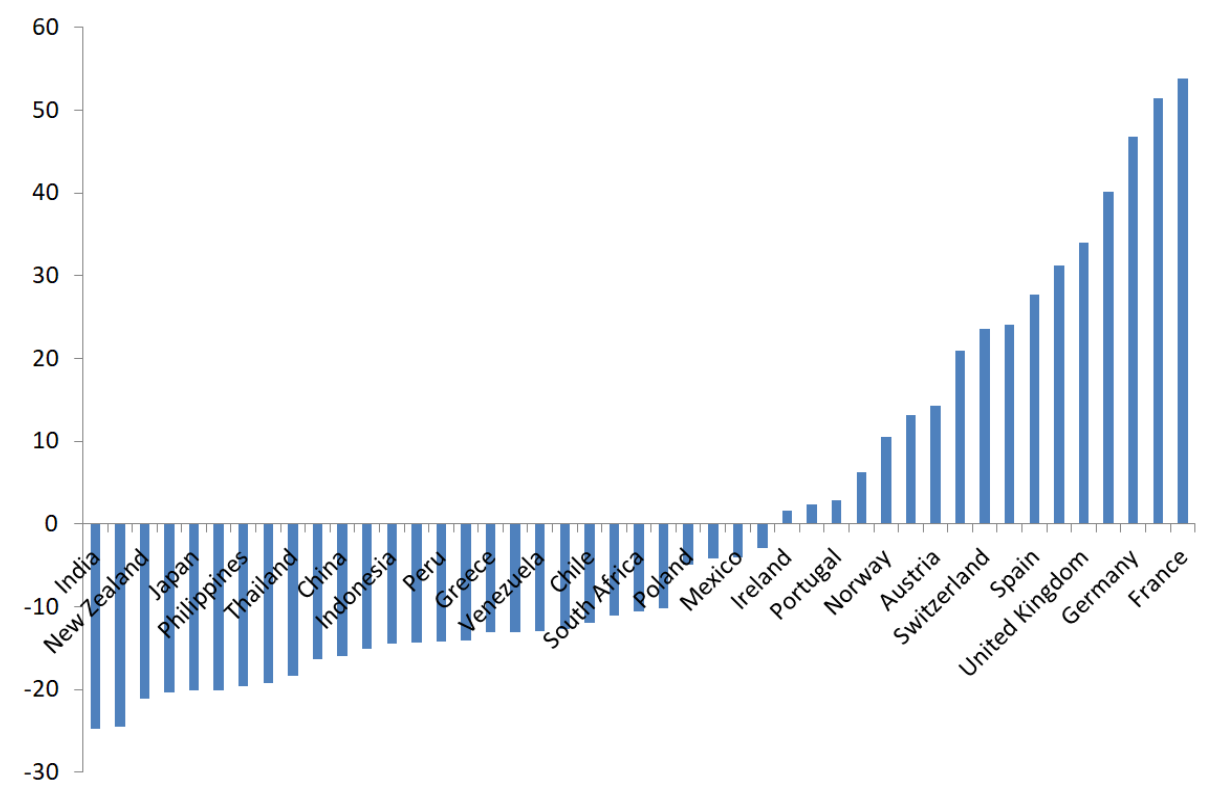

Fig. 7 Average net directional volatility spillover across markets Source: Author's calculation and presentation based on data from Diebold-Yilmaz. database, http://financialconnectedness.org/research.html

From this illustration it is obvious that more integrated countries in economic, trade, and financial terms are net transmitters of shocks, while less integrated, developed, and developing countries are net receivers.

\section{CONCLUSION}

The aim of the paper was to analyse volatility spillovers. Total, net, and directional volatility spillover measures were presented and analysed for four main global financial market segments - stocks, bonds, FX, and CDS. The analysis indicates that spillovers were strongest during distress periods - the global and sovereign debt crisis and Brexit. The transmission of the shocks was most pronounced in the CDS market, followed by equities, bonds, and FX. Directional and net directional measures indicate that developed and more open and connected countries are predominant transmitters of shocks, while less developed and less integrated markets are net receivers of volatility spillovers and potential contagion. In addition, adequate preventive and in-time economic policy actions are able to stop or mitigate volatility shock transmission and negative network contagion effects. 


\section{REFERENCES}

Alter, A. \& Beyer, A. (2012). The dynamics of spillover effects during the European sovereign debt turmoil. (CFS Working Paper, No. 2012/13), Frankfurt a. M: Goethe University, Center for Financial Studies (CFS). Retrieved from: http://nbn-resolving.de/urn:nbn:de:hebis:30:3-266587. Accessed on: 20 September 2018.

Antonakakis, N. \& Vergos, K. (2013). Sovereign bond yield spillovers in the Euro zone during the financial and debt crisis. Journal of International Financial Markets, Institutions and Money, 26, 258-272.

Diebold, F.X. \& Yilmaz, K. (2009). Measuring Financial Asset Return and Volatility Spillovers, With Application to Global Equity Markets. Economic Journal, 119, 158-171.

Diebold, F.X. \& Yilmaz, K. (2012). Better to Give than to Receive: Forecast-Based Measurement of Volatility Spillovers. International Journal of Forecasting, 28(1), 57-66.

Duncan, A.S. \& Kabundi, A. (2013). Domestic and foreign sources of volatility spillover to South African asset classes. Economic Modelling, 31, 566-573.

Koop, G., Pesaran, M. H. \& Potter, S. M. (1996). Impulse response analysis in non-linear multivariate models. Journal of Econometrics, 74, 119-147.

Louzis, P.D. (2015). Measuring spillover effects in Euro area financial markets: a disaggregate approach. Empirical Economics, 49 (4), 1367-1400.

Pesaran, M. H. \& Shin, Y. (1998). Generalized impulse response analysis in linear multivariate models. Economics Letters, 58, 17-29.

Reinhart, C. M. \& Rogoff, K. S. (2008). Is the 2007 US subprime crisis so different? An international historical comparison. American Economic Review, 98, 339-344.

Sims, C. A. (1980). Macroeconomics and reality. Econometrica, 48, 1-48.

https://onlinelibrary.wiley.com/doi/epdf/10.1002/jae.2585

http://financialconnectedness.org/research.html

\section{EFEKTI PRELIVANJA VOLATILNOSTI NA NAJVEĆIM SEGMENTIMA GLOBALNOG FINANSIJSKOG TRŽIŠTA}

Cilj ovoga rada jeste predstavljanje $i$ analiza mera finansijske povezanosti i prelivanja volatilnosti na važnim segmentima globalnog finansijskog tržišta - tržištu akcija, tržištu obveznica, CDS tržištu i deviznom tržištu. Prezentovane su i analizirane ukupna, neto i mera koja pokazuje smer prelivanja volatilnosti ukazujući na nivo povezanosti konkretnog tržišnog segmenta među zemljama kao i na nivo prelivanja volatilnosti u kriznim nasuprot stabilnim periodima.

Ključne reči: finansijska povezanost, opšti VAR, prelivanja volatilnosti, segmenti globalnog finansijskog tržišta 